1 DISTRIBUTION AND POPULATION OF CHUKAR PARTRIGDE (ALECTORIS

2 CHUKAR) IN DISTRICT BAJUAR, KPK, PAKISTAN

4 Durr e Shahwar ${ }^{1}$, Atufa Kawan ${ }^{2}$, Hina Mukhtar ${ }^{3}$, Inam Ullah ${ }^{1}$

$5 \quad{ }^{1}$ Department of Forestry and Wildlife Management, University of Haripur KPK, Pakistan

$6 \quad{ }^{2}$ College of Fisheries, Huazhong Agricultural University, Wuhan, China

$7 \quad{ }^{3}$ College of Food Science and Technology, Huazhong Agricultural University, Wuhan, China

9 Corresponding Author:

10 Dr. Durr e Shahwar

11 shahwar.awan201@gmail.com

$12+923345451969$

14 Author contributions

15 Durr e Shahwar and Inam Ullah designed, conducted research and wrote the manuscript, Atufa

16 Kawan and Hina Mukhtar analyzed data and and read the manuscript.

\title{
17 Abstract
}

18 The Chukar Partridge (Alectoris chukar) is a wild bird of the Phasianidae family. In Pakistan, it

19 occurs in a wide range of rugged, sloping and dry areas, rising to the interior of the Himalayas,

20 the western Himalayas and plains, the higher piedmont valleys on the dry slopes of the

21 Baluchistan provinces and Punjab and Sindh provinces. It is the "national bird" of Pakistan,

22 however, little is known about its ecology and reproduction in the northern part of the country.

23 This study investigated the existence, distribution and population of birds in the Bajaur region of

24 Khyber Pakhtunkhwa (KP) Province from December 2019 to August 2020. Usually in the early 
morning (5 to $78 \mathrm{AM}$ ) and evening (4 to $9 \mathrm{pm}$ ). The areas occupied by Alectoris chukar mainly include Mulberry, Ficus banyan, Gum arabic, Arabian acacia, Barberes lycium, Dilberia sisso, Melia azedarach, Ailanthus, Alalthus altissima, Zanthoxylum alatum, Olea europaea, Olea europaea, Ingres, Celtis eriocarpa and Pinus wallichiana. Habitat destruction (overgrazing, mowing and landslides) caused by hunting, shooting, capture, explosives, excavation, and road construction is the main threat to existing wildlife (including Alectoris chukar).

Keywords: Alectoris chukar, Chukar Partrigde, Bajaur, population, distribution

A common game bird of the family Phasianidae is Chukar Partridge (Alectoris chukar Gray, 1830). Its origin in Asia includes Palestine, Lebanon, Turkey, Iran, Afghanistan, Pakistan and India, from the western Himalayas to Nepal (Birdlife International, 2016). It is usually found at mean sea level (amsl) between $2000 \mathrm{~m}$ and $4000 \mathrm{~m}$ above sea level, but it is also found at $600 \mathrm{~m}$ in Pakistan (Rasmussen and Anderton, 2005). Chukar can be found in the field in gatherings of 2-4 or typically 5-7 birds. From March, they begin to mix and raise the brood in the middle of early April to July, depending on the elevation. The breeding begins at low altitude right on time when compared to the higher rise (Roberts, 1991) that it travels to snow-topped fields in the Himalayas and does not begin to rise until late June. Roberts (1991) stated that Chukar nesting occurred over a long period of time, depending on altitude and latitude. Some birds in Himalayas ascend to alpine pastures and do not start breeding until late June. However, breeding can start early (from late March) at lower elevations. In the Salt Range, the main nesting season is April to May with a typical clutch size of 6 to 9 eggs, but the clutch size may range from 15 to 19 eggs in heavier rainfall areas. 
47 Chukar Partridge is the national bird of Pakistan and a wild bird. However, in the country's

48 natural environment, there is insufficient scientific data on its ecology and breeding. The area

49 Bajuar is contained within its local area, but there is no previous data record for this area. The

50 current study aims to investigate the distribution and population of Chukar partridge in the

51 Bajaur region of Khyber Pakhtunkhwa province.

\section{Methods}

\section{Study Area}

The current research has been carried out in the Bajaur area between $34.795100^{\circ}$ latitude and $71.540594^{\circ}$ longitude in the southeast. The Bajaur district was a semi-independent area before

571960 and was considered a place with inconvenient transportation. In 1960, Bajaur was declared

58 a subdivision of the Malakand region, and in December 1973 it was declared a Federal Tribal

59 Area (FATA). The Bajaur district is administratively divided into two districts, namely the Khar

60 district and the Nawagai district and seven tehsils. The Bajaur district borders the Mohmand

61 district in the southwest, and the Dir district borders Afghanistan in the northwest. The Bajaur

62 region includes an arid subtropical area with harsh winters and hot summers. Winter begins in

63 December and lasts until February, during which the temperature drops below zero. May to

64 September is the warmest month of the year. The average annual rainfall is $800 \mathrm{~mm} / \mathrm{year}$. The

65 terrain is mostly mountainous (Figure 1).

66 Nine months research survey was conducted from December 2019 to August 2020 to determine

67 the distribution and population of Alectoris chukar in Bajaur district. To carry out the research 68 area was divided into three main research zones, A, B and C (Figure 1; Table 1). During the 
69 investigation, direct and indirect methods were used to collect information about its distribution

70 and population. Calls, feathers, feces and information collected from local residents, hunters and

71 game observers in the area provide the best indirect evidence for determining its status. The

72 survey was usually scheduled from 5 am to 8 am and $4 \mathrm{pm}$ to $9 \mathrm{pm}$. The survey was taking under

73 the following material; camera, water, battery, rifle, blank page, ballpoint, binocular, hunting

74 Chukar, brown cloths.

75 The number of calls of Chukor and time spent at each site were recorded. Calling frequency was

76 calculated by using the following formula:

77

78 Calling frequency $=\underline{\text { Total number of calls }}$

Total observation time

80

81 ANOVA (One-way Analysis of Variance) was used to analyze data recorded on call counts 82 during different months of the study period.

\section{Results}

86 A total of 92 different Chukar signs were recorded at seven sampling points, including 150 direct

87 sightings, 391 calls, 130 feces, 60-foot prints and 190 feathers. Among the seven selected 88 sampling sites, Zulam had the largest species signs (26.09\%), followed by Corala (19.57\%), and

89 Cicandro $(5.43 \%)$ had the least signs. Due to the dense vegetation, perhaps due to the sparse 90 population of Chuko (Chukar) in the area, it is difficult to spot birds in the wild. Chukar's call 91 was also heard in the study area (Table 2). The most calls were recorded at Zulam and Matako 
92 sites (80per call), and the fewest calls (two) were recorded at Sikandro site. Difference between

93 the first and second call was 14-6 seconds during the breeding season, while during non-

94 breeding season, this difference was 50-60 seconds or even more than 2-3 min. In the same

95 way, number of calls per minute (calling frequency) was also the highest as 0.15 during January,

$96 \quad 0.3$ in February and 0.28 in March indicating the onset of breeding season, while recorded 0.1

97 in April, 0.07 in May, 0.05 in June, 0.02 in July and 0.01 in August. This was the time when males and females started to pair up. One Way Analysis of Variance (ANOVA) showed a significant difference $(\mathrm{df}=8, \mathrm{~F} 2.90, \mathrm{p}<0.05)$ in call counts during different months of the year.

Entirety of 181 birds was assessed in 25 areas of the three study zones. In Study Area A, the average total number during the entire study period was estimated to be 60 individuals. However, the winter population $(n=80)$ was higher than the summer population $(n=39)$. The population of District A fluctuated in different months of the two seasons. The population was higher in January $(n=87)$, but declined in February $(n=70)$, then increased in March and April $(n=81, n$

$105=84$ ), and in summer, from May to August, the population showed a slight growth trend (Table 3). Among the three regions, study area B had the highest population $(n=73)$, with an average population of 73 in summer and 72 in winter. The highest population in May $(n=80)$, followed by a decline in June $(n=69)$ and July $(n=71)$, but the population in August gradually increased $(n=73)$. In the different months of winter and summer, the population of this bird in area $\mathrm{C}$ was 110 similarly affected. The average number of 54 birds in winter fell to the average number of 48 111 birds in summer, with the highest in March $(\mathrm{n}=56)$, followed by January $(\mathrm{n}=55)$, February $(\mathrm{n}=$ 112 54) and April $(\mathrm{n}=52)$. Also in the summer, the population in May $(\mathrm{n}=34)$ gradually increased 113 after June $(\mathrm{n}=41)$, July $(\mathrm{n}=54)$, and then declined in August $(\mathrm{n}=40)$ (Table 3). Overall 114 seasonal data shows that there is almost an upward trend, reaching the maximum in January $(\mathrm{n}=$ 
115 218). This figure may be due to the reproductive output of this bird. The reason for the decline 116 may be the change of its activities, because the climate has gradually become bad, most zones of

117 the study area are not covered by crops and other vegetation, interns may change the behavior

118 and activities of this bird. During summer and early winter, the bird was also found to be more

119 active and vocal. The low summer populace may be because of the reasons that in this season the

120 bird involved high elevation, which some of the time are distant and can cause inconsistencies in

121 assessing its populace. It is national bird of Pakistan, locally known as zark for male and zarka

122 for female. It can live rocky locations, mountainous in mixed habitat types. Atmosphere is bone-

123 dry to semiarid, temperature shifts and water is commonly accessible from dissipated sources,

124 nest basic scratches lined feather or grass in brushy areas or rocky.

125 Discussion

126

127 IUCN categorizes Chukor Partridge as the "least concern", with a stable population trend and a 128 very large population (Birdlife International, 2016). Rich et al. (2004) estimated its global 129 population as c. 2,000,000 people. However, there are reports that its population has decreased

130 from some parts of the world, such as in Europe, where it is estimated that the small population 131 has decreased by nearly 30\% in 11.7 years (three generations) (BirdLife International, 2015).

132 During the investigation, the bird was found to be very active at dawn and dusk, and was found 133 to be engaged in various activities such as sitting, calling, eating and flying during the 134 investigation. We recorded various signs of Chukar in the field, including its calling, feathers, 135 feces, direct sightings and footprints to confirm its occurrence in the study area. The largest 136 overall sign of birds was recorded in Zulam. During the field investigation, it was discovered that 
137 the Chukor was related to lower region bushes, including the Dodona viscosa as reported by 138 Roberts (1991).

139 The current survey was conducted in Bajaur district from December 2019 to August 2020. 140 Chukar reproduces once a year according to environmental conditions. Breeding occurs from 141 April to July, with 7 to 21 eggs laid in each season, and an average incubation time of 24 142 (Christensen, 1996). According to (Del Hoyo et al., 1994; Cole et al., 1995; Christensen, 1996; 143 Perrins, 2003), different results were obtained in this survey (Table 3), since they proposed April 144 to July rearing season for Alectoris chukar and the current investigation recorded reproducing 145 season from early March to mid of August. Range eggs per season, 7 to 21 and were gathered 5 146 to 20 eggs for each season. The most well-known call was a low throw, chuk, chuk utilized by

147 both genders that changes bit by bit to a chukar, chukar and can be gotten with significant 148 distances (Del Hoyo et al., 1994; Cole et al., 1995; Christensen, 1996; Perrins, 2003). Our results 149 showed that the male Chukar in the Bajaur district started to call in January and early February, 150 and then a pairing occurred. The peak breeding season was March and April. Our results on 151 Chukar Partridge's pairing and reproduction records are consistent with earlier studies by Del 152 Hoyo et al. (1994), Christensen (1996) and Mahmood et al. (2019).

153 Deforestation, agricultural activities, habitat destruction caused by infrastructure, landslides, and 154 disturbance caused by population growth are the main threats to bird fauna (Khalid et al., 2017). 155 According to reports, the earlier mentioned threat is the main threat to the Chukar partridge 156 population in Bajaur.

157 Acknowledgement 
160 We are thankful to all the local peoples who support us throughout our research.

$161 \quad$ Literature cited

162

163

164

165

166

167

168

169

170

171

172

173

174

175

176

177

178

179

BirdLife International. European red list of birds. Office for Official Publications of the European Communities, Luxembourg. 2015.

BirdLife International. The IUCN red list of threatened species 2016: e.T22678691A89355978.http://dx.doi.org/10.2305/IUCN.UK.2016-3.RLTS.

T22678691A89355978.en. Downloaded on 06 November 2019.

Christensen C. Chukar: Alectoris chukar in A Poole, F Gill, eds. The Birds of Noth America Philedelphia, PA: The Academy of Natural Sciences of Philedelphia, 1996; 1-20.

Cole F, Loope L, Medeiros A, Raikes J, Wood C. Conservation implications of introduced game birds in high elevation Hawaiian shrub land. Conservation Biology, 1995; 9:306-313.

Del Hoyo J, Elliot A, Sargatal J. Alectoris Chukar. in Handbook of the birds of the world, New World vultures to guinea fowl. Barcelona: Lynx Edicons. 1994; 2:485-486.

Khalid S, Awan MS, Minhas RA, Ashraf N, Ahmed KB, Shafi N, Abassi S. Distribution and habitat use of avian fauna of Rawalakot city and its surroundings, Azad Jammu and Kashmir, Pakistan. Pakistan J. Zool. 2017; 49: 2331- 2334.

Mahmood T, Ahmad I, Akrim F, Hamid A. 2019. Breeding Ecology of Chukor Partridge (Alectoris chukar) in Lower Dir District, Khyber Pakhtunkhwa, Pakistan. Pakistan Journal of Zoology. 2017; 51(1). DOI: 10.17582/journal.pjz/2019.51.1.265.271 
180 Perrins C. Firefly encyclopedia of birds. Firefly Books Ltd., Buffalo, New York, USA, 2003.

181 Rasmussen PC, Anderton JC. Birds of South Asia: The Ripley Guide. Volume Smithsonian 182 Institution \& Lynx. 2005; 120.

183 Rich TD, Beardmore CJ, Berlanga H, Blancher PJ, Bradstreet MSW, Butcher GS, Demarest DW, Dunn EH, Hunter WC, Inigo-Elias EE, Martell AM, Panjabi AO, Pashley DN, 185 Rosenberg KV, Rustay CM, Wendt JS, Will TC. Partners in flight: North American landbird conservation plan. Cornell Lab of Ornithology, Ithaca, NY. 2004.

187 Roberts TJ. The Birds of Pakistan. Oxford University Press, Karachi, Pakistan. 1991. 


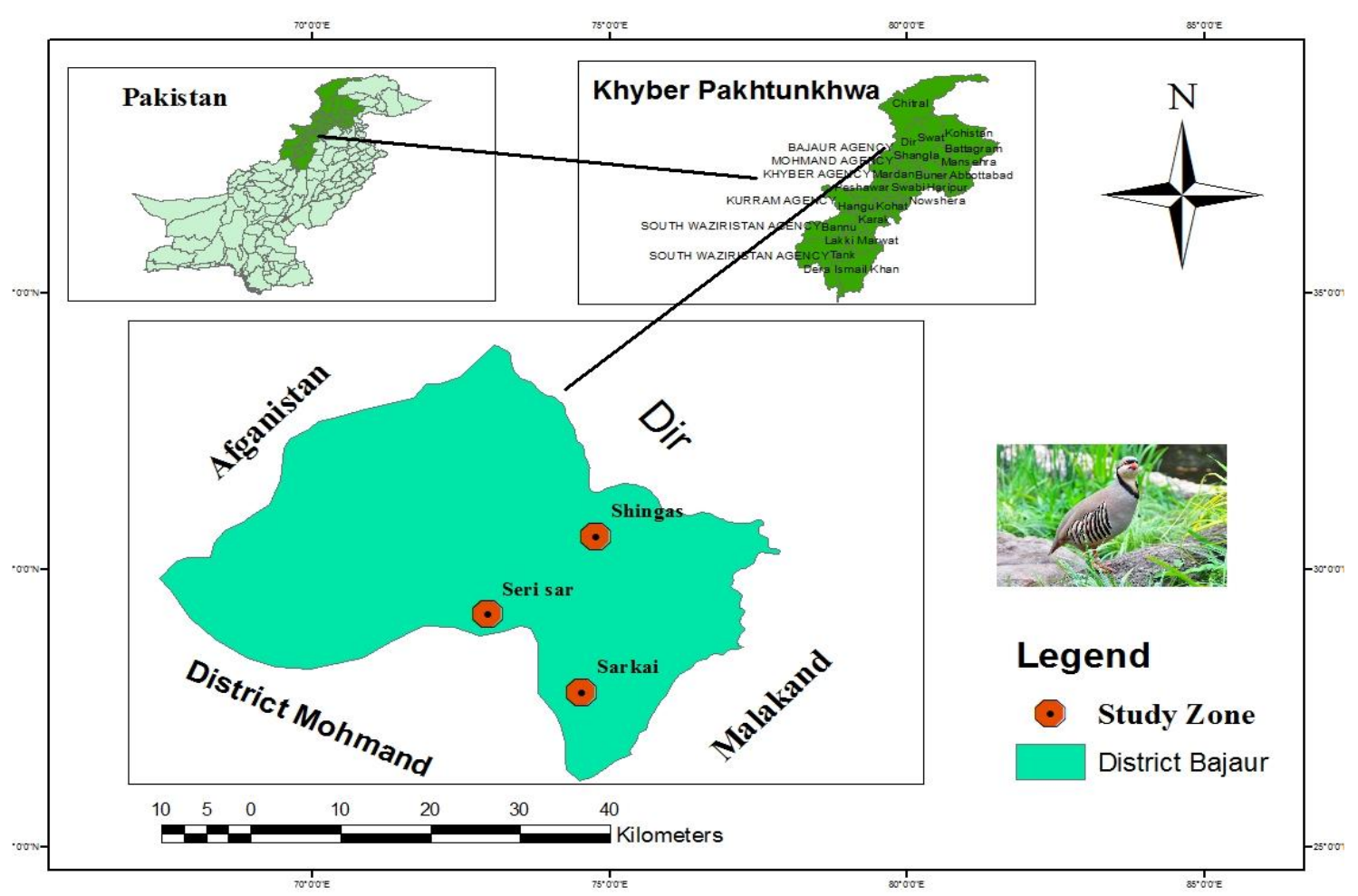


204 Table 1: Selected sampling sites in Bajaur District for collection of data on distribution and

205 population of the Chukor Partridges

206

207

Study Zone Sampling sites Sub sites

208

\begin{tabular}{lll}
\hline A & Shingas & 13 \\
B & Serkai & 5 \\
C & Seri Sar & 7 \\
\hline
\end{tabular}

209

210

211 Table 2: Field signs of Alectoris chukar recorded at different sampling sites in District Bajaur

212 during field survey

213

\begin{tabular}{lccccccc}
\hline Site & Calls & $\begin{array}{l}\text { Field } \\
\text { sightings }\end{array}$ & Feathers & $\begin{array}{c}\text { Fecal } \\
\text { droppings }\end{array}$ & $\begin{array}{c}\text { Foot } \\
\text { prints }\end{array}$ & $\begin{array}{c}\text { Total } \\
\text { signs }\end{array}$ & $\begin{array}{l}\text { Percentage } \\
(\%)\end{array}$ \\
\hline Zulam & 8 & 4 & 7 & 2 & 3 & 24 & 26.09 \\
Matako & 8 & 2 & 2 & 1 & 1 & 14 & 15.22 \\
Kolala & 7 & 4 & 4 & 2 & 1 & 18 & 19.57 \\
Badagai & 5 & 1 & 4 & 3 & 1 & 14 & 15.22 \\
Sikandro & 2 & 1 & 0 & 2 & 0 & 5 & 25.43 \\
Hayaty & 3 & 1 & 2 & 1 & 0 & 7 & 17.61 \\
Shinkot & 6 & 2 & 0 & 2 & 0 & 10 & 10.87 \\
\hline
\end{tabular}

214

215

216 
Table 3: Population estimation of Alectoris chukar in different months during the year 2020

219

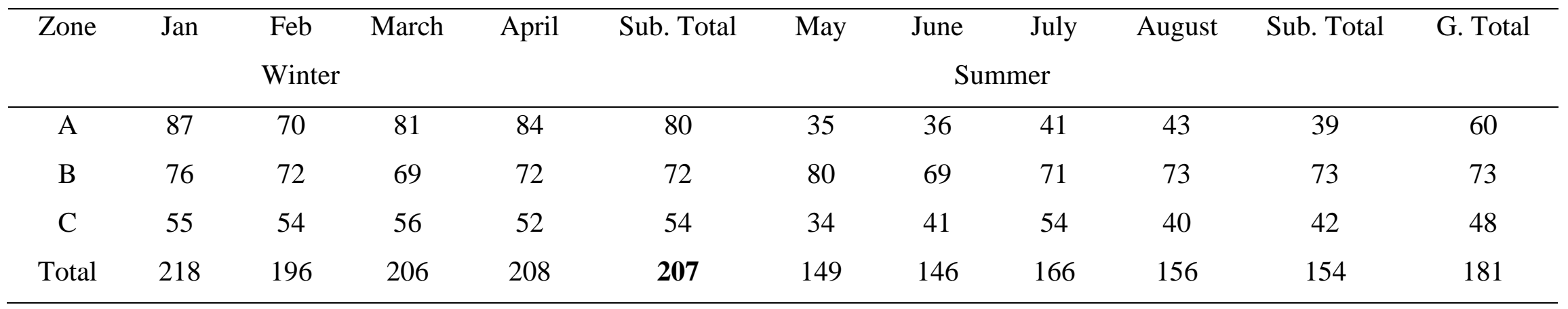

220 